\title{
New Day Films: Collective Aesthetics and the Collection
}

\author{
Elizabeth Coffman \\ Loyola University Chicago, ecoffma@luc.edu
}

\section{Erica Stein}

Follow this and additional works at: https://ecommons.luc.edu/communication_facpubs

Part of the Communication Commons, and the Film and Media Studies Commons

\section{Recommended Citation}

Coffman, Elizabeth and Stein, Erica. New Day Films: Collective Aesthetics and the Collection. Female Authorship and the Documentary Image: Theory, Practice, and Aesthetics, , : 22-39, 2018. Retrieved from Loyola eCommons, School of Communication: Faculty Publications and Other Works,

This Book Chapter is brought to you for free and open access by the Faculty Publications and Other Works by Department at Loyola eCommons. It has been accepted for inclusion in School of Communication: Faculty Publications and Other Works by an authorized administrator of Loyola eCommons. For more information, please contact ecommons@luc.edu.

\section{(c) $)(1) \Theta$}

This work is licensed under a Creative Commons Attribution-Noncommercial-No Derivative Works 3.0 License.

(c) The Authors 2018 


\section{NEW DAY FILMS: COLLECTIVE AESTHETICS AND THE COLLECTION}

\section{Elizabeth Coffman and Erica Stein}

New Day Films was founded in 1972 - on the cusp of sweeping changes in documentary and feminist filmmaking practice - by four documentarists who were unable to gain distribution in the bottleneck of the New York nonfiction filmmaking scene (Figure 1). Despite these challenges, their films about the everyday texture of women's lives were in demand with audiences as the women's movement grew across the country. ${ }^{1}$ Today, New Day is one of the most financially stable nontheatrical distribution collectives in North America, boasting more than 165 members and $\$ 1 \mathrm{~m}$ in yearly revenues. ${ }^{2}$ Films distributed by the collective have been screened, broadcast and awarded around the world, studied in media journals, discussed at organising events, showcased in museums, and collected by libraries. New Day's collective (and its collection) provide compelling objects of study for the history of gender and documentary authorship.

In interviews spanning thirty-five years, from 1978 to 2015, founders (Figure 2) and newer members alike attribute New Day's success not only to its identity as a collective but also to two specific forms this category implies. First, New Day is a vehicle for self-distribution, wherein each member is responsible for the reproduction, audience engagement strategies, and direct marketing of their own film. Yet each member is also a part owner, and both individual profits and the cooperative's overhead are calculated through a share ladder a transparent division of New Day's total profits - voted on by the members every year. ${ }^{3}$ Second, while New Day's institutional identity and practices are derived from a model of participatory democracy and the pluralism it values, 


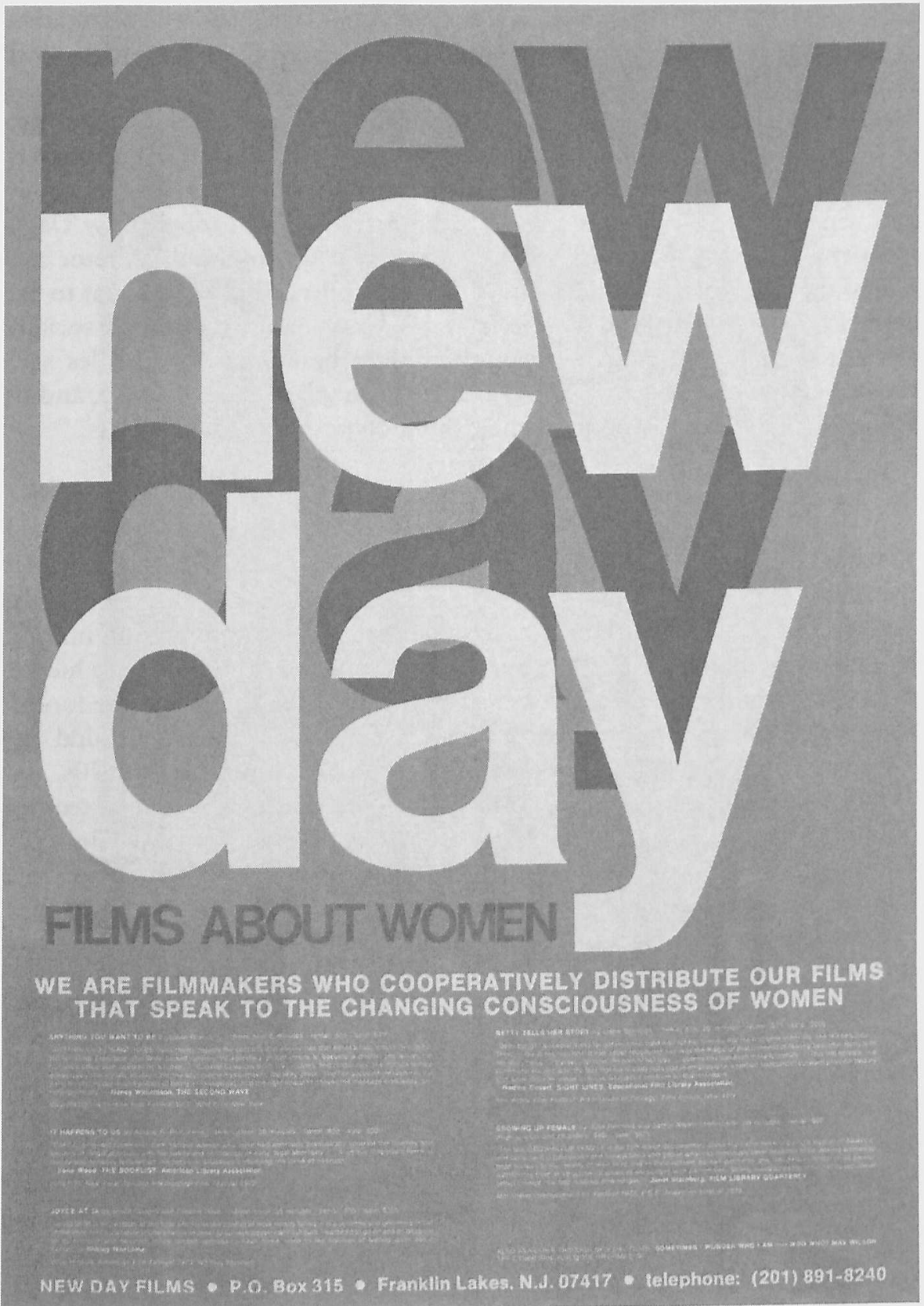

Figure 1 New Day Films poster, 1973. Courtesy of Liane Brandon. 
one of the collective's most prominent features is its highly unified presentation of its content - its films - on the Web, in promotional materials, and in other venues. New Day's titles, honoured with three retrospectives at the Museum of Modern Art in New York and recently acquired by Duke University's Archive of Documentary Arts, are marketed and often consumed as a historically significant, curated collection with a distinct house style. The complex play between individualised activism and collectivity threads through New Day's identity as both a dominant US independent educational film distributor and one of the few surviving feminist documentary collectives so important to the early 1970s. ${ }^{4}$ This creative tension is also felt in New Day's current socially integrated business practices, which depend on branding its film titles as a curated collection, the participatory democracy implied by its by-laws, and its pioneering of digital distribution and exhibition possibilities.

\section{REAList Polyphony}

Cinema is rarely produced as a singular operation. The director may attract the most obvious credit for creative filmmaking choices, but the figure of the auteur does not begin to capture the collaborative forms of decision making and influence that occur at all stages of media production - both in the hierarchical, financially driven Hollywood production environment and the looser, idea-driven forum of the media collective. With opportunities behind the scenes and on screen in Hollywood still restricted for women in the 1970s, and $16 \mathrm{~mm}$ Bolex and Sony Portapak cameras becoming readily available, women began to form media collectives. These collectives, such as New Day Films, Iris Films, and Women Make Movies (WMM), taught skills to women and other populations often denied access to production technologies while distributing materials that were viewed as being too controversial or aesthetically unusual for television or movie theatres.

Three years after its founding, New Day released Chris and Bernie (directed by Bonnie Friedman and Deborah Shaffer; USA: New Day Films, 1974), a short $16 \mathrm{~mm}$ documentary about two single mothers who live together in order to afford raising their children. The young women, both divorced, have children under the age of six. Chris is trained as a nurse but is on welfare, while Bernie is trying to learn carpentry. As Chuck Kleinhans described in his 1975 review of the film in Jump Cut, 'We see Bernie building a stairway while she tells us, in voice-over, that she didn't want to be a secretary and fought the welfare bureaucracy to get into an OEO (Office of Equal Opportunity) carpentry training program that was "only for men".' The film evinces a documentary aesthetic that is neither expository nor overtly experimental - an observational slice of single parenthood and poverty in the 1970s. 'What we have in this new genre of political documentary, the discussion film,' Kleinhans 


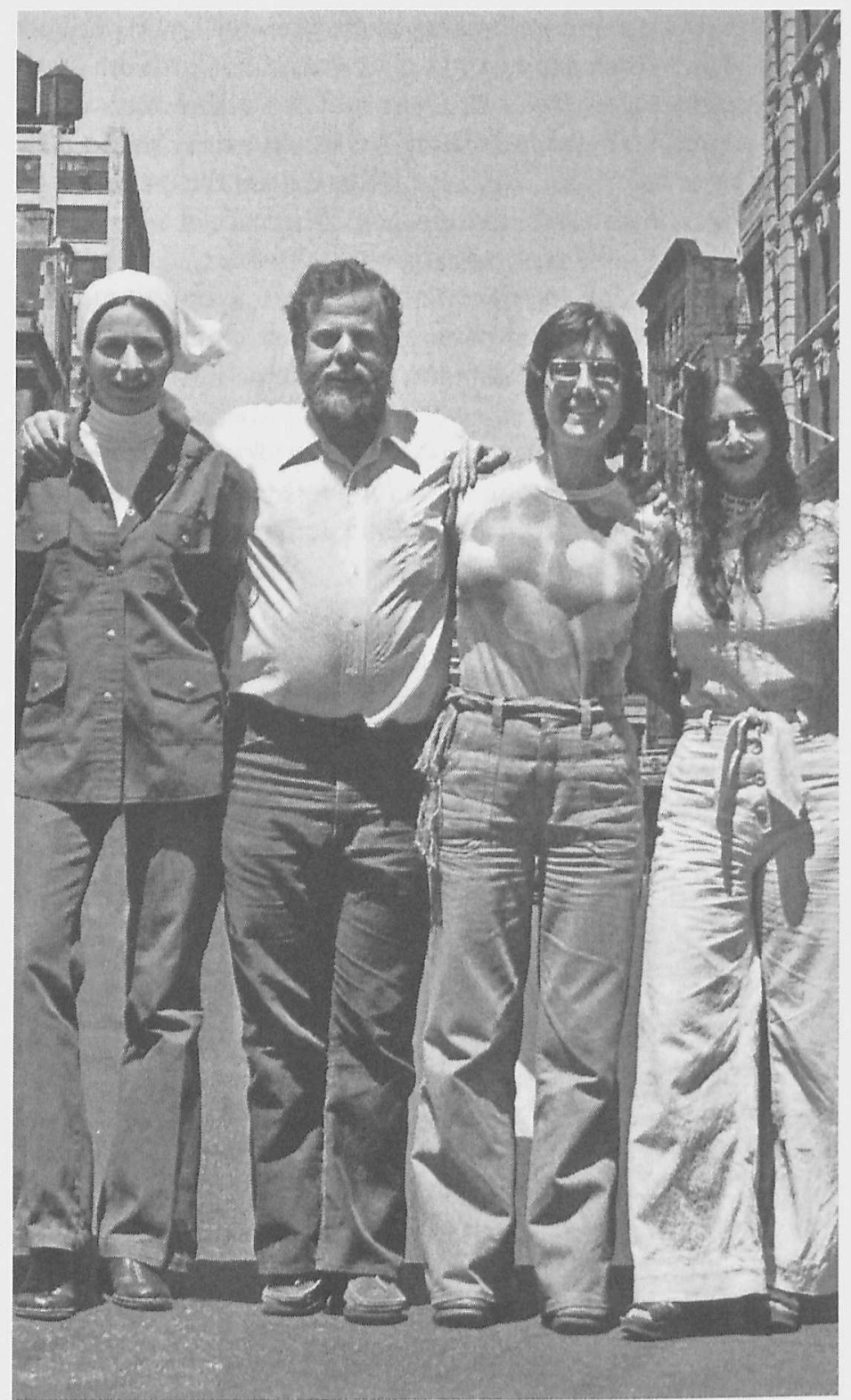

Figure 2 New Day founders Liane Brandon, Jim Klein, Julia Reichert and Amalie Rothschild, 1976. 
continues, "is the process and political struggle of everyday life. ${ }^{5}$ The film initially proved difficult to distribute, a challenge familiar to New Day's founders. Two of those founders, Julia Reichert and Jim Klein, who later received Academy Award nominations and Emmy Awards for their work, claimed that in the world of New York documentary filmmaking in the late 1960s and early 1970s, professional distributors barely paid filmmakers after the company took its cut and that some distributors, such as the Film-Makers' Cooperative in New York, were 'so into underground and experimental film that we could see our potential audience would never get that catalogue'. ${ }^{6}$ Instead, Reichert and Klein, along with other founding members, Liane Brandon and Amalie R. Rothschild, developed aesthetic and economic strategies that addressed and created not only a wider audience interested in the women's movement, labour issues and political debates about reproductive rights, but also an audience that could produce themselves as a politically active community through their engagement with the films.

Reichert identifies New Day as a constitutive element of second-wave feminism:

The whole idea of distribution ... was to help the women's movement grow. Films could do that; they could get the ideas out. We could watch the women's movement spread across the country just by who was ordering our films. First it was Cambridge and Berkeley. I remember the first showing in the deep South. ${ }^{7}$

Reichert also describes getting '30-40 bookings a month' in 1971-2 for one of the first and best-known New Day films that she directed with Klein, Growing Up Female (USA, 1971). ${ }^{8}$ A chronicle of the social development of girls and women through a range of cultural, economic, and racial contexts, Growing Up Female's initial bookings were at universities such as Harvard and Vassar College but then expanded to 'churches, nursing schools, technical schools' and 'junior colleges, Catholic high schools'. ${ }^{9}$ For her part, Brandon recalls that, while it was a for-profit business (as it remains to this day), New Day negotiated fees with exhibitors on the basis of need,

so that consciousness-raising groups and anyone we thought would be interested would have the tools to educate, organize, and spread the word. Different groups used [the films] in different ways - to educate, to plan 'actions' (if the group was so inclined), to plan screenings in schools, churches, union halls, local theaters, etc. ${ }^{10}$

As Brandon suggests, the exhibition venue and the films' content encouraged the audience to act as a collective, especially in their immediate response to 
the screenings. In 1975 Kleinhans named both Growing Up Female and Chris and Bernie as exemplary 'discussion' films that appeal to 'ordinary working people', and implied that discussions among audience members could lead to debate, dissent, or even organising. ${ }^{11}$ At their height, these audience actions amounted to what Jane Gaines calls 'political mimesis', in which the bodies of the viewers and the bodies on screen are linked in a reproduction of actions. ${ }^{12}$ The moment of political mimesis may occur through an orchestrated rejection or resistance to charged, overdetermined images on screen, such as dolls or pornography, the use of voice-overs or a dialectical recognition of the performance of gender, as in Liane Brandon's groundbreaking Anything You Want To Be (USA, 1971) and Betty Tells Her Story (USA, New Day Films, 1972) (Figure 3). The New Day films that helped the women's movement grow in the 1970s tended to show that, as Kleinhans argues about Chris and Bernie, 'small
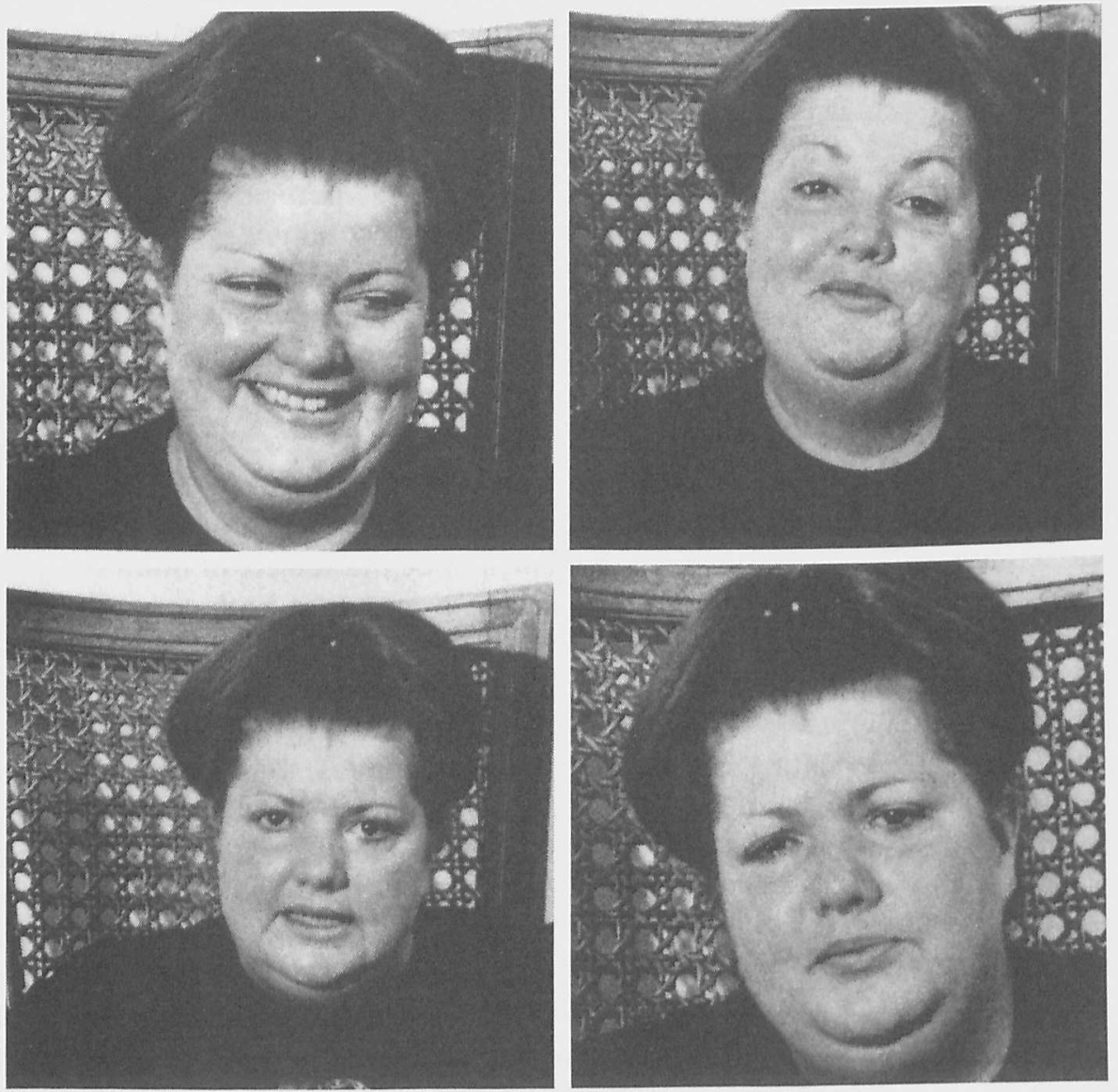

Figure 3 Betty Tells Her Story (New Day Films, 1972). 
changes are no small thing. [They are] the very stuff of change, the foundation for those dramatic public and mass activities called demonstrations, strikes, and revolutions'. ${ }^{13}$ This mirroring between the institutional structure of the organisation producing the films and the audiences viewing them had a crucial intermediary: the aesthetics of the films themselves.

New Day's aesthetic, and its articulation of that aesthetic with its status as a collective as well as the broader concept of collectivity, must be understood in the wider context of 1970s Anglo-American feminist film practice and theory. This connection is especially evident in a 1978 New German Critique roundtable discussion among editors, scholars, curators, and filmmakers about the status of feminist film theory. ${ }^{14}$ After the discussion oscillates between the benefits of Marxist and psychoanalytic analyses of feminist film content for Hollywood and independent films, the editors pose the question of collectives. Is the collective model a more successful alternative for producing feminist content, they wonder, by involving female producers and evading the male-centred hierarchy of the studio system? Judith Mayne suggests, 'I think it's important to be more precise about what we mean by collectivity.' She describes the strategies of a worker's group that used video recording at a factory strike as one example that includes collective participation. But there are other ways to understand a 'collective aesthetic'. Mayne continues, 'The strategic interest of film collectives is, I think, a different relationship with what's being filmed or who's being filmed, which I hope would necessitate a different relationship between who's watching the film and who's made the film. ${ }^{15}$ As B. Ruby Rich notes, filmmaking is 'a dialectical experience' for women - from being the object of spectacle to suddenly producing it. ${ }^{16}$ Rich's comment resonates with the most crucial problematic explored by feminist theorists and filmmakers in the 1970s, and for decades afterwards: under what circumstances is it (ever) possible for women to be the subject of film?

Women's ability to assume this position is a matter of both the collective and the aesthetic because the dominant film aesthetic uses classical narrative and structured looking positions to simultaneously reduce women to the bearer of the look and to the patriarchal construction of the feminine as other, as Woman. The resulting objectified figure was most famously elucidated by Laura Mulvey in her essay 'Visual pleasure and narrative cinema', published in 1975, and Mulvey joined figures such as Rich, Mayne, Claire Johnston, E. Ann Kaplan and others in calling for a filmmaking practice that could produce women both as the subject of film and as a collective. That is, a praxis that both communicates women as subjects and as a collective, a group structured and delimited by patriarchal oppression as well as diverse embodied experiences of race, class, gender and sexuality yet with the possibility of producing relations and works that exist outside of this structure and thereby helping to transform it. This complex goal produced multiple theories, praxes and texts. 
The intervening years have collected, and perhaps (over)simplified them, into roughly two groups. The first marries psychoanalytic film theory to a modernist, allusive, experimental aesthetic in order to explore how social apparati, including film, construct women as Woman, and what some of the resulting consequences are. In the 1970s, this was the tactic of collectives such as WMM and films such as Thriller (directed by Sally Potter; UK: Arts Council of Great Britain, 1979) and Riddles of the Sphinx (directed by Laura Mulvey and Peter Wollen; UK: British Film Institute, 1977). At the same time, another strand of theory and praxis that stressed consciousness raising, organising and more directly Marxist action emerged in collectives such as the Boston Newsreel (of which New Day co-founder Liane Brandon was a member) or California Newsreel Film Collective, and films such as 'Up Against the Wall, Ms America' (Newsreel \#22, 1968) and 'The Woman's Film' (directed by Louise Alaimo and Judy Smith; USA: California Newsreel Films, 1971). ${ }^{17}$ These films, usually nonfiction, were known for using the documentary form to produce a transparent, realist style that explored individual women's experiences, and often studied the collectives they formed in order to change those experiences. ${ }^{18}$

New Day is one of the last remaining - and surely the most financially stable - organisations that made up this second strand, often referred to as 'the feminist realist' tradition. Perhaps because of this association with a kind of naive realism, New Day's aesthetic has generally been read as the lack of one. In 1994, twenty years after the heyday of realist feminist documentary film and the rise of reflexive, formalist avant-garde work, Alexandra Juhasz set out to redefine realism as not simply a footnote on the road to the complexity of Trinh T. Minh-ha, Chantal Akerman and Tracey Moffat, but rather a politically viable adaptation of realist methods that both depicted acts of individual becoming and produced collective consciousness-raising. ${ }^{19}$ At the outset of her article, Juhasz noted that

perhaps the most disturbing consequence of [the academy's dismissal of realist feminist documentary] is the loss of these films for revaluation due to the economic relationship between film scholarship and alternative film distribution: only twenty years later, they are difficult, if not impossible, to find. ${ }^{20}$

At the close of the article, following a list of films screened at a 1992 Whitney Museum of American Art retrospective of feminist cultural objects, Juhasz notes that 'the distributors who handled many of these films are long out of business'. ${ }^{21}$ Notably, while other exemplars of the realist style suffered economic collapse within twenty years of their founding, surfacing only in museum retrospectives that treat their aesthetic as indicative of a truncated path in a larger cultural movement, New Day has been the subject of three 
different film programs at the Museum of Modern Art, in 1983, 1996 and 2011. These exhibits, while they foreground New Day's most prominent early work, also feature new films on a variety of topics.

Juhasz's comments and MOMA's curatorial influence suggest that 'feminist realism' does constitute an aesthetic. In fact, the same year New Day had its first MOMA retrospective, which featured 'signature' New Day titles such as Growing Up Female, It Happens to Us (directed by Amalie R. Rothschild; USA, 1972), Anything You Want To Be (directed by Liane Brandon; USA, 1971) and Chris and Bernie, documentary scholar Bill Nichols published an article that suggested how this aesthetic should be understood. ${ }^{22}$ Nichols identified a distinct mode he named 'the third style', which exhibits the influence of both expository and observational techniques while subordinating them to its use of interviews. In so doing, this mode transfers 'the voice of the documentary' from a central point of authorial enunciation in voice-over or in the camera's objective gaze to a decentralised and subjective experiential authority held by a variety of talking head interviewees.

New Day's films have long availed themselves of this technique, just as its institutional structure and distribution tactics function as analogues to it. From the beginning, New Day preserved and disseminated a wide variety of feminist creative output, and just as the exhibition contexts encouraged a range of responses to its films, so too were the aesthetics of the films themselves 'collective', employing a hybridised use of Nichols's 'third style' and offering many potential moments of recognition. Early New Day films present a range of women's everyday experiences, often using a collage aesthetic that precludes an identification of any one subject or experience as normative, while simultaneously insisting that each experience is delimited by a patriarchal society. Thus, the films retain a sense of the individual need and possibilities for collective support within a system, while showing the force of that system as it is felt on the individual level - similar to how self-distribution within a cooperative structure preserves the specificity of individual projects while allowing for their proliferation and recognition as part of a broader strategy, form or mode. The aesthetics of these films align with Jane Gaines's description of a radical remembering/viewing process for the film viewer, 'translating our interest in the viscerality of film-going' into 'the consequent radicalization of the spectator'. ${ }^{23}$ Gaines reinvestigates how moving images achieve a radical audience response, how a film 'moves' a spectator 'to get up and do something'. She acknowledges that these questions are 'fraught with issues of measurement, causality, and disciplinary boundary', but suggest that critics should 'take a different tack':

I want to see the historical bodies-in-action on the screen as having a mimetic relation to the bodies of the viewers. In this theorization, viewing 
bodies re-produce the political movement imaged on the screen in the world of their present. Here the radical film has the power to make things happen because of this special screen/world relation that I call political mimesis. $^{24}$

New Day's early work shows how a 'collective aesthetic', in this case one derived from Nichols's third style and informed by the conditions of production and exhibition, can help to achieve a politically mimetic film event. Films like Growing Up Female and Chris and Bernie effect a political mimesis that runs both from the screen to the audience and from the institutional structure to the screen.

This aesthetic is particularly evident in Growing Up Female, whose structured play of unity and disharmony chronicles the lives of women in the US from four to thirty-four. Although its subject is human development, the film is circular rather than linear, emphasising the issues presented as collectively, rather than individually, experienced. This results in extreme symmetry within and between segments, culminating in the linking of the opening scene and the film's final moments. This cyclic logic encompasses the suggestion that the film occurs within a day - the opening shots depict a mother taking her daughter to class and the closing shots show the daughter being picked up from school - binding the diverse lives of the subjects observed within a unifying temporal structure. This resonates with the film's audiovisual strategy, which produces the film's interviews as extremely ambiguous. The interviews feature the six primary subjects and those figures of authority who embody the institutions with the most impact on their lives. These figures often voice the conventional patriarchal wisdom surrounding feminine development. For example, the elementary school teacher in the opening segment notes in voice-over that little girls are 'mean', 'jealous' and 'competitive' in comparison with little boys, with whom they do not like to play. The voice-over is accompanied by a series of shots of the teacher's classroom. The master shots display mixed-gender groups of children playing together while two-shots and close-ups show little girls sharing with, grooming and comforting one another. The scene challenges one of Nichols's critiques of the third style, namely that it does not question or evaluate the authority of interviewees. ${ }^{25}$ Here, the film utilises audiovisual montage to cast doubt on the teacher's assessment and to emphasise the selective and constructed nature of the social reality she reinscribes, implying its effects on a collective, as well as individual, level.

Growing Up Female further displays its third style traits by utilising something similar to Nichols's 'intertitles' - an apparently authorial voice that interrupts the traditional voice-over or interview - to suggest the complexity of its subjects' own experiences and perceptions. This is particularly noticeable in the segment featuring Terry, a sixteen-year-old African American aspiring 
cosmetologist from a small town. At the outset of her segment, Terry declares herself satisfied with her life goals and current romantic situation, both of which she professes should be primarily determined by her male partner, with whom she shares the screen. This view is reiterated by her high school guidance counsellor, who runs a course on marriage that stresses domestic sphere responsibilities for women, assumes that married women will work only in the home and that they will defer to their husbands in all matters of import. As her segment continues, Terry's discussion of her situation and goals becomes more nuanced, as when she suggests that her desire to find a boyfriend who would assume a dominant role in the relationship is at least partially due to the norms of her community. The segment concludes with Terry's completion of her marriage class and declaration of her intention to leave her town because 'the farther away I get, the better it might be'. The scene is accompanied by the Bob Dylan-penned 'I Shall Be Released' on the soundtrack, which connects Terry's desires to civil rights-tinged rhetoric as well as the liberationist aesthetics of the counterculture. Of course, this structure could be read as implying that this consciousness-raising film does not so much educate the audience as it produces its interview subjects as in desperate need of instruction by the filmmakers and the second wave feminism they represent. Such a reading resonates with the many critiques of vérité and direct cinema documentaries as inherently dismissive and even exploitative of their subjects, as well as with ethnographic critiques of emotional manipulation from musical soundtracks, even when positioned ironically. ${ }^{26}$

Despite moments of sound/image aesthetic intervention, as Juhasz observes, perhaps more 'often political producers are drawn to realist strategies'. ${ }^{27}$ As both a feminist filmmaker and an academic scholar, Juhasz notes the ambivalence that she feels about including 'realist' aesthetic strategies in her video projects about women who are HIV positive while teaching the problematic patriarchal nature of making these same aesthetic choices in the classroom: "it disturbs me that the theory I respect and use is often at odds with the media I make and watch. ${ }^{28}$ Juhasz argues for the importance of the interviews in It Happens To Us, which problematise assumptions about representation and identification. "Words that have rarely been said by women out loud form a revisionist history that unifies a range of positions as one potential for a shared feminist identity.' By speaking these words on camera, from multiple 'positions', Juhasz suggests that a number of spectator identification points are possible, including 'the political action that this collective articulation of oppression will inspire, ${ }^{29}$ the kind of relationship between screen and audience, the kind of aesthetic, that Gaines calls political mimesis. In this frame, early New Day films' focus on women in collective terms and observations on how individuals do and do not perceive themselves as part of this collective are used to develop a doubled vision, an aes- 
thetic that simultaneously depicts the reality that creates women as Woman/ object as well as the collective thought and action capable of revealing this reality as constructed.

\section{Collective vs Collection}

New Day's institutional culture and films, then, successfully achieve an aesthetic of collectivity. However, New Day has survived its original contemporaries in part by comprehensively marketing itself as a collection. As the story of New Day's founding suggests, the collective regarded both the ability to preserve a film with like-minded work and also to track the film's exhibition - as well as the impact of that exhibition - as its central purpose. This preservation feature lingers today, as New Day sells its works to educators and scholars as an impeccably curated collection, assuring its users of a certain level of quality (even predictability) and of bold, insightful content. This is evident in the cooperative's promotional materials and in its digital extensions, including the descriptions of films within its archive, MOMA's holdings of New Day films, as well as its three MOMA shows. While collective action and governance are hallmarks of both New Day and feminist politics in general, the collection as an organising structure tends toward an erasure of such possibilities. In her work on the collection, Susan Stewart argues that to collect is to forget, so that a collection stands for an entire experience, place or moment, while erasing differences among the collection's elements. ${ }^{30}$ New Day's marriage of its economic and cultural survival as a collective to branding as a collection potentially complicates its ability to produce an aesthetic of collectivity.

Stewart's fears about the collection are potentially evident in all three MOMA shows, where New Day's status as a commercial concern and as an historical entity whose membership, output and politics have evolved over its forty-year existence is partially suppressed. New Day's relationship with MOMA dates back to 1982, ten years after the collective's creation. In that year, MOMA was approached by New Day as part of its tenth anniversary celebration and asked to participate. ${ }^{31}$ The museum billed the collective in terms of both its feminist and activist roots and as 'a model cooperative of and for independent filmmakers [that] through its documentary films has participated in and charted many of the social changes in the United States over the last decade'. ${ }^{32}$ The exhibit reflected New Day's current catalogue and history. However, the films were separated into programs that downplayed their historical difference and various political emphases in favour of shared topicality and audience.

The 1996 retrospective, also curated by Berger, followed a similar logic, and was publicised with reference to New Day as an historically important 'cooperative' entity yet without an account of its historical transformations. ${ }^{33}$ 
Thus, although New Day is acknowledged as a distributor, this is couched almost in terms of New Day being a kind of small peer to MOMA, preselecting and collecting worthy works that the museum will now 'screen' for maximum importance and interest before screening them for its audience, even as the 'venerable New Day artists', many of whose films are exactly those housed in MOMA's archives, are separated from their work, which is not individually named or attributed. By presenting itself as an archival collection in both internal and external sites, New Day takes on the ability to construct itself - not its films, directors or history - but the institution itself as an object (worthy) of study, the fact of whose existence itself testifies to the success of its projects and its organisational practice. The museum's celebration of New Day diffuses the idea of historical evolution - from a somewhat exclusionary second wave feminist outlook to one engaged with an entire range of social justice issues - in favour of the image of an ahistorical archive of educational film.

New Day's embrace of the collection - and MOMA's parallel acknowlegement of New Day's own curatorial practices - does recapitulate several of the qualities that make this form inimical to the collective aesthetic and at odds with the kind of political mimesis attempted by New Day's preferred exhibition contexts, yet it is key to its institutional branding. While collections may reinforce some ideological erasures, they can also help to mediate a certain strand of public memory by countering 'social amnesia'. ${ }^{34}$ Forty years after New Day Films contributed to a national discussion about gender equity and stereotypes, a social and political 'backlash' to these concerns has grown. ${ }^{35}$ While the collection may tend to erase history, new digital storage models can act as a kind of counter archive that allows for collective - even mimetic? engagement with the past. New Day's recent donation of materials to Duke University's Archive of Documentary Arts displays some of the potential of such models. Kirston Johnson, the archive's head curator, described how 'Our collecting informs the history of documentary arts just as much as [the collections]'. ${ }^{36}$ Because the Duke collection is interested in the filmmaker's creative process as well as in distribution history, they include ancillary prints and materials along with exhibition film and video prints. ${ }^{37}$ For instance, the sales and rental invoices from the New Day collection may help to track the importance of film exhibition for the early establishment of Women's Centers around the country. Johnson also plans to complete oral history interviews with the New Day founders to complement the archive's holdings, a co-archival or ethnographic act that starts to mimic the initial stages of documentary production. New Day's archival moment relates to the present digital revolution in that both allow for easier access to representations of our collective past, representations that may help reorder earlier assessments of forgotten, ignored or misremembered histories. 


\section{Collecting Small Changes}

The aesthetic strategies displayed in many of the founding films and the mimetic tactics employed by their directors remain key components of New Day's activity today, although membership, the aesthetic modes employed, and the films' exhibition contexts have all diversified. New Day's pioneering digital distribution platform weaves together the cooperative's past and future by emphasising the discussion aesthetic of many of its films. The platform simultaneously renews and reinvents possibilities for how 'discussions' may occur: in single-channel and interactive screenings among a geographically scattered, sometimes atomised audience.

New Day Digital, spearheaded in 2008 by New Day filmmakers Paco de Onís, Jeff Tamblyn and Peter Cohn, was an early streaming platform for independent documentaries hosted by Seattle Community Colleges television. ${ }^{38}$ Recognising the collaborative opportunities of the digital platform, New Day has chosen to promote films that facilitate the forging of connections, dissemination of memories or sharing of political strategies among digital visitors. Some of the most compelling interactive documentary projects connected with New Day filmmakers are Granito: How to Nail a Dictator (directed by Pamela Yates; USA, 2011) and Rebecca Snedeker and Luisa Dantas's Land of Opportunity (USA, 2010). Through their content platforms, these New Day documentaries allow for collective commentary and interactive feedback surrounding issues of poverty, education and citizenship - a logical expansion from New Day's beginnings with discussions of films that feature critiques of patriarchy.

The digital platform suggests that the logic of the collection can help progressive media achieve its ends. This is particularly evident in Granito, which both performs and unravels the processes of history (Figure 4). Co-produced by Skylight Labs, New Day Digital leader Paco de Onís, Pamela Yates and Peter Kinoy, Granito recuts footage from an earlier documentary that Yates and Kinoy worked on, When the Mountains Tremble (directed by Newton Thomas Sigel and Pamela Yates; USA: New Day Films, 1983). The original film covered the Guatemalan genocide by interviewing corrupt government officials as well as indigenous rebel armies. Traveling with the leftist guerillas, a young Yates profiled Inés - whose name was actually María Magdalena Hernández - a Mayan guerrilla fighting for fair wages, property rights, and the recognition of her people. Granito's title is taken from Hernández's own fateful words in When the Mountains Tremble: 'We are making a big effort, each contributing our tiny grain of sand, our granito, so that our country can be free', words and images that Granito returns to repeatedly.

Granito suggests the ways in which a collection can be compatible with the aims of the collective, just as When the Mountains Tremble's collecting and 


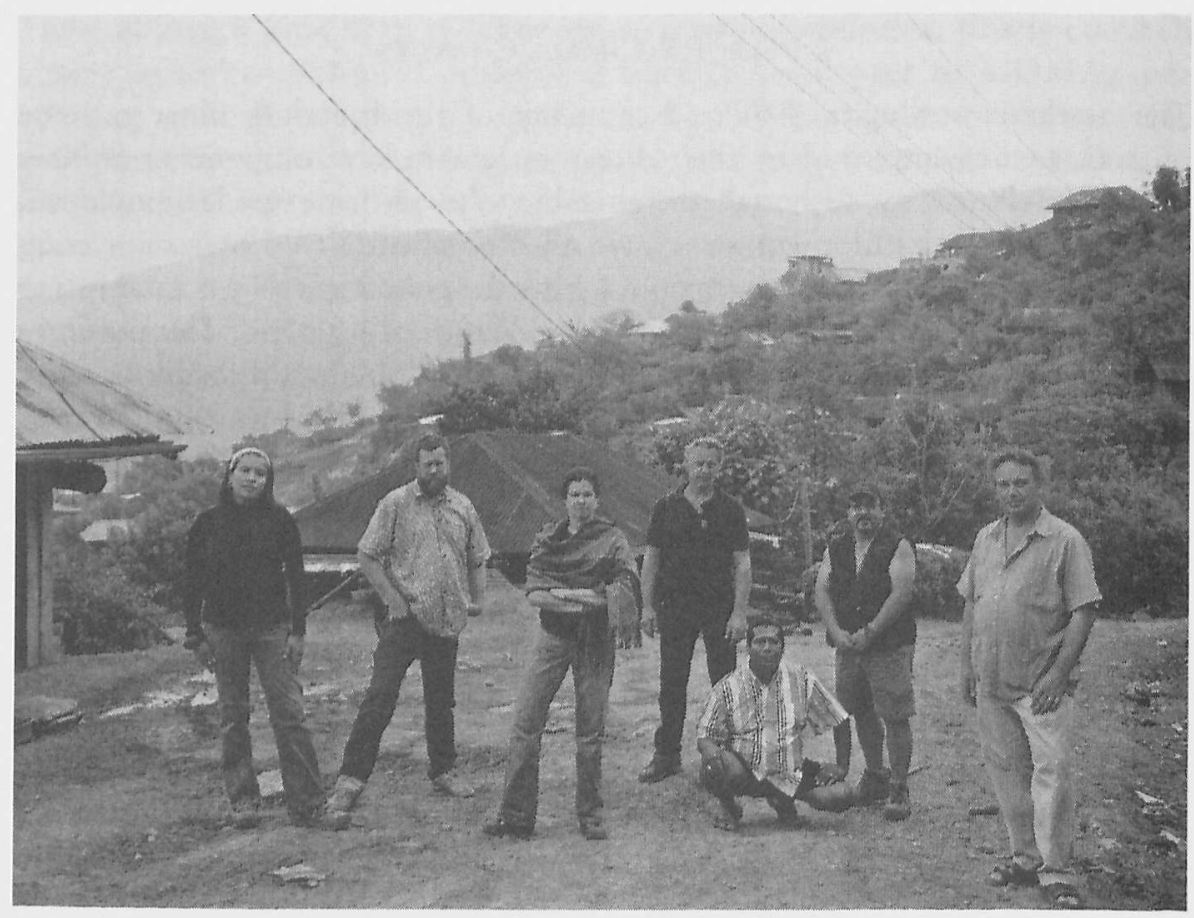

Figure 4 Director Pamela Yates in the Guatemalan Highlands with the crew filming Granito: How to Nail a Dictator. Photo: Dana Lixenberg.

recording of the conflict was itself a political act: the preservation of the events depicted in the film contradicts the regime's official narrative of its actions and locates the actions of the rebel armies in a wider context. The film was used as a politically mimetic object within and outside of Guatemala, most notably in the case of Yates's 1983 interviews of former dictator Efraín Ríos Montt. Yates records Ríos Montt bragging about his responsibilities, 'I control the army', a statement that was used as forensic evidence at his trial for genocide in May 2012. In its turn, Granito reopens this history in its engagement with When the Mountains Tremble, turning the form of the collection against its expected uses. Distributed digitally by New Day and contextualised within a complex social media environment predicated on presence, Granito is characterised by the digital prostheses that so often accompany the contemporary film collection, as well as by shared aesthetic decision making practices from the staff of Skylight Pictures and Labs.

On New Day's website, Yates describes how the 'collective concept' behind the co-production, direction and editing of When the Mountains Tremble and Granito allowed her, de Onís and Kinoy (Skylight Pictures) to develop 'our approach to political documentary storytelling'. ${ }^{39}$ This 'collective concept' 
continues with the social media updates to the memorial website that accompanies Granito, 'Every Memory Matters' (a multimedia project that Skylight identifies as a 'platform', developed at the Bay Area Video Coalition Producers Institute)..$^{40}$ The memorial website includes Yates's description of Hernández in 1980, months before her death. After contact from Hernández's brother on Facebook, Yates and de Onís posted a letter from her that they found in their files, as well as many other emotional memorial documents and photos, on 'Every Memory Matters'. As a result of the ongoing interactive storyworld of Granito more outreach initiatives and two new interactive platforms, 'IJCentral', on the international criminal court, and 'Anatomy of a Trial', examining the 'strategies behind the historic 2012 Ríos Montt genocide trial', have been developed or are in development by Skylight Labs. With the support of New Day Films, Skylight continues to provide compelling examples of how women's storytelling history may achieve social justice through the outreach strategies and aesthetic and institutional strengths of both the collective and the collection.

\section{Notes}

1. Liane Brandon, email message to Elizabeth Coffman, 3 August 2012. Brandon is an award-winning filmmaker and cofounder of New Day Films along with Julia Reichert, Jim Klein and Amalie Rothschild. See 'Liane Brandon', New Day Films, $<$ www.newday.com/filmmaker/42> (last accessed 9 October 2015).

2. Beverly Seckinger, email message to authors, 8 September 2014. Seckinger is a filmmaker and producer affiliated with New Day Films. 'Beverly Seckinger', New Day Films, <www.newday.com/filmmaker/132> (last accessed 9 October 2015).

3. For information on the share ladder, application processes and distribution practices, see New Day Films' website, <www.newday.com/content/apply-join-us> (last accessed 17 August 2015).

4. While New Day is notable simply for its decades-long operation, the collective is perhaps even more remarkable for its continued adherence to its original economic model and mission, especially when compared to WMM. Like New Day, WMM recently celebrated its forty-year anniversary as a women's film collective. The biggest difference between the two distributors today is that New Day has continued to operate successfully using collective and sustainable decision-making models, while WMM's comeback is more the product of a single individual's (Debra Zimmerman) efforts to develop it into an organisation that is more focused on independent film distribution. See Debra Zimmerman and Patricia White, 'Looking back and forward: a conversation about women make movies', Camera Obscura, no. 82, 2013, pp. 147-55; B. Ruby Rich, 'The confidence game,' Camera Obscura, no. 82, 2013, pp. 157-65.

5. Chuck Kleinhans, 'Chris and Bernie: the virtues of modesty', Jump Cut, no. 8, 1975 , p. 6.

6. Quoted in Julie Lesage et al., 'Interview with Julia Reichert and Jim Klein: New Day's way,' Jump Cut, no. 9, 1975, p. 21.

7. Lesage, 'Interview with Julia Reichert and Jim Klein', p. 22.

8. Kleinhans, 'Chris and Bernie: the virtues of modesty', p. 6.

9. Lesage, 'Interview with Julia Reichert and Jim Klein', p. 22 
10. Brandon, email message to Elizabeth Coffman, 3 August 2012.

11. Kleinhans, 'Chris and Bernie: the virtues of modesty', p. 6.

12. Jane Gaines, 'Radical attractions: the uprising of '34', Wide Angle, 21/2, 1999, p. 103.

13. Kleinhans, 'Chris and Bernie: the virtues of modesty', p. 6.

14. Michelle Citron, Julia Lesage, Judith Mayne, B. Ruby Rich and Anna Marie Taylor, 'Women and film: a discussion of feminist aesthetics', New German Critique, no. 13, Special Feminist Issue, Winter 1978, pp. 82-107.

15. Ibid. p. 96.

16. Ibid. p. 87.

17. See John Hess, 'Notes on U.S. radical film, 1967-90', Jump Cut, no. 21, November 1979 , pp. 31-5; 'Brandon tells her story: back in the (New) Day of social issue films', Documentary Magazine, International Documentary Association, <http:// www.documentary.org/magazine/brandon-tells-her-story-back-new-day-social-iss ue-films> (last accessed 12 December 2016).

18. A third potential group currently receiving attention were early proponents of more direct interactivity, systems theory and followers of Gregory Bateson's concept of cybernetics. Writers and videomakers such as Beryl Korot and Phyllis Segura, and collectives, Raindance Corporation and Videofreex, were drawn to video in large part because of the creative, interactive potential for recording, playback and feedback between subjects and cameras. Phyllis Segura references talking with William Burroughs about a 'band' of people spread across a road, all with video cameras recording the same thing from a variety of perspectives, in 'Creating radical software: personal account', Rhizome, 28 April 2015.

19. Alexandra Juhasz, 'They said we were trying to show reality - all I want is to show my film: the politics of the realist feminist documentary', Screen 35, no. 2, Summer 1994, pp. 171-91.

20. Juhasz, 'They said we were trying to show reality', p. 173.

21. Ibid. p. 190.

22. Bill Nichols, 'The voice of documentary', Film Quarterly, 36/3, 1983, pp. 17-30.

23. Gaines, 'Radical attractions: the uprising of ' 34 ', p. 111.

24. Ibid. p. 103.

25. Nichols, 'The voice of documentary', pp. 25-7.

26. Such critiques are epitomised by Calvin Pryluck's review of direct cinema and cinéma vérité's aesthetics in 'Ultimately we are all outsiders: the ethics of documentary filming', Journal of the University Film Association, 28/1, Winter 1976, pp. $21-9$.

27. Juhasz, 'They said we were trying to show reality', p. 174.

28. Ibid. p. 176 .

29. Ibid. pp. 182-3.

30. New Day curates via a long-established process of voting by committee. See <https:// www.newday.com/content/apply-join-us $>$ (last accessed 18 February 2016). Susan Stewart, On Longing: Narratives of the Miniature, the Gigantic, the Souvenir, the Collection (Durham, NC: Duke University Press, 1984), pp. 151-3.

31. Isabel Hill, email message to Erica Stein, 4 August 2012.

32. Stuart Klawans, 'The Museum of Modern Art presents a birthday tribute to New Day Films, New York, Film Press Office, Museum of Modern Art, May 1983.

33. MOMA program describes, 'For the twenty-fifth anniversary of New Day Films, the Department of Film and Video has organised two programs from the cooperative's recent acquisitions, and a retrospective of eleven films and videos by venerable New Day artists, including Ralph Arlyck, Joyce Chopra, Jane Gilooly, Isabel Hill, Julia Reichert, and Amalie S. Rothschild. Also presented are some of New 
Day's earliest films, from MOMA's archives.' Graham Leggat, 'Fall advance schedule of film and video programs', New York, Film Press Office, Museum of Modern Art, August 1996, p. 32.

34. Francis X. Blouin, Jr and William G. Rosenberg, Processing the Past: Contesting Authority in History and the Archives (Oxford: Oxford University Press, 2011), p. 110.

35. In 2010 Harvard University students organised a 'Feminist coming out day' in response to the perceived 'backlash', which also references Susan Faludi's Backlash: The Undeclared War Against American Women (New York: Random House, 1991). See <http://feministcomingoutday.com/>.

36. Phone conversation with Elizabeth Coffman, 19 December 2012.

37. Liane Brandon confirmed that the combination of the library's ability to preserve and screen film as well as the Sally Bingham collection helped to convince New Day founders to select Duke University for their archive donation. Liane Brandon, in discussion with Elizabeth Coffman, July 2012.

38. Beverly Seckinger, email message to authors, 17 February 2013.

39. Pamela Yates, quoted in Granito: How to Nail a Dictator (USA, New Day Films, 2011), <www.newday.com/film/granito> (last accessed 17 August 2015).

40. 'About the project', Granito: Every Memory Matters, <http://www.granitomem. com/acerca-del-proyecto/s (last accessed 3 February 2016). And Skylight media platforms, <http://skylight.is/media/\#platforms> (last accessed 3 February, 2016).

\section{Filmography}

Chris and Bernie [film] (Bonnie Friedman and Deborah Shaffer, USA, New Day Films, 1974).

Growing Up Female [film] (Julia Reichert and Jim Klein, USA, New Day Films, 1971). Anything You Want To Be [film] (Liane Brandon, USA, 1971).

Betty Tells Her Story [film] (Liane Brandon, USA, New Day Films, 1972).

Thriller [film] (Sally Potter, UK, Arts Council of Great Britain, 1979).

Riddles of the Spbinx, film, (Laura Mulvey and Peter Wollen, UK, British Film Institute, 1977).

Up Against the Wall, Ms America [film] (Newsreel \#22, USA, Third World Newsreel Film Collective, 1968).

The Woman's Film [film] (Louise Alaimo and Judy Smith, USA, California Newsreel Films, 1971).

It Happens to Us [film] (Amalie R. Rothschild, USA, New Day Films, 1972).

Granito: How to Nail a Dictator [film] (Pamela Yates, USA, New Day Films, 2011).

Land of Opportunity [film] (Rebecca Snedeker and Luisa Dantas, USA, New Day Films, 2010).

When the Mountains Tremble [film] (Newton Thomas Sigel and Pamela Yates, USA, New Day Films, 1983).

Granito: Every Memory Matters [website] (Pamela Yates, Peter Kinoy and Paco de Onis, USA, Skylight Labs, 2011).

Dictator in the Dock [website] (Pamela Yates, Peter Kinoy and Paco de Onis, USA, Skylight Labs, 2013).

IJCentral [website] (Pamela Yates, Peter Kinoy and Paco de Onis, USA, Skylight Labs, 2008).

Anatomy of a Trial [website] (Pamela Yates, Peter Kinoy and Paco de Onis, USA, Skylight Labs, (in production)). 


\title{
FEMALE AUTHORSHIP AND THE DOCUMENTARY IMAGE
}

Theory, Practice and Aesthetics

\author{
Edited by Boel Ulfsdotter and \\ Anna Backman Rogers
}


Edinburgh University Press is one of the leading university presses in the UK. We publish academic books and journals in our selected subject areas across the humanities and social sciences, combining cutting-edge scholarship with high editorial and production values to produce academic works of lasting importance. For more information visit our website: edinburghuniversitypress.com

(C) editorial matter and organisation Boel Ulfsdotter and Anna Backman Rogers, 2018 (1) the chapters their several authors, 2018

Edinburgh University Press Ltd

The Tun - Holyrood Road

12 (2f) Jackson's Entry

Edinburgh EH8 8PJ

Typeset in 10/12.5 pt Sabon by

Servis Filmsetting Ltd, Stockport, Cheshire

Printed and bound in the United States of America

A CIP record for this book is available from the British Library

ISBN 9781474419444 (hardback)

ISBN 9781474419451 (webready PDF)

ISBN 9781474419468 (epub)

The right of the contributors to be identified as authors of this work has been asserted in accordance with the Copyright, Designs and Patents Act 1988 and the Copyright and Related Rights Regulations 2003 (SI no. 2498). 